\title{
Non-Financial Reporting in Romania in the pre-Directive 2014/95/EU Period (1990-2013)
}

\author{
Professor Adriana TIRON-TUDOR, PhD, Teodora Viorica FĂRCAŞ, PhD, Ioana DRAGU, PhD, \\ Ecaterina Monica MOISE, PhD student \\ Babeş-Bolyai University, Cluj-Napoca, Romania
}

\begin{abstract}
In Romania, a country with a former centralised economy governed by a communist regime up to 1990, there was a tradition for reporting non-financial information, which includes corporate social responsibility, sustainability and environmental issues. This paper aims to analyse the transition to a free-market economy and a democratic society that encompasses complex socio-economic transformation processes, with a specific focus on non-financial reporting as a measure of its progress. Using the neoinstitutional normative theory framework, a qualitative methodology-based analysis of the national regulations concerning corporate reporting. This paper aims to outline the steps taken by Romania toward a market economy, through the lens of non-financial voluntary or mandatory reporting in for different types of entities.
\end{abstract}

Key terms: non-financial reporting, Romania, voluntary/mandatory disclosure, Directive, NFRD

Acknowledgements: The results presented in this paper represents a part of the research conducted by the team in the frame of INTEREST-INTEgrated REporting for SMEs Transparency project, ERASMUS+ KA2 - Strategic Partnership 2019-1-HU01-KA202-060911

JEL Classification: M40

To cite this article: Adriana Tiron-Tudor, Teodora Viorica Fărcaş, loana Dragu, Ecaterina Monica Moise, Non-Financial Reporting in Romania in the pre-Directive 2014/95/EU Period (1990-2013), CECCAR Business Review, № 5/2020, pp. 63-72, DOI: http://dx.doi.org/10.37945/cbr.2020.05.07

\section{Introduction}

The stakeholders' interest for non-financial information (NFI) concerning environmental, social and governance (ESG) metrics increased in time (Manes-Rossi et al., 2018). Responding to this demand, companies started to produce various reports concerning a variety of issues related to ESG aspects of their activities in general, voluntarily, following more or less different standards or doing it in their own style (Tschopp and Huefner, 2014; Dyduch and Krasodomska, 2017; Makarenko and Sirkovska, 2017).

Governments and supranational structures, such as the European Commission showed their sensitivity towards NFI information regarding social responsibility, environmental and climate changes and sustainable development, and started to promote regulations and recommendations for a better way to manage these matters, culminating with the mandatory requirements of Directive 2014/95/EU (NFRD), effective beginning with 2018 annual reports of 2018, which regulate the mandatory non-financial reporting for large undertakings and groups in Europe (Dumay et al., 2019).

In this context, we intend to analyse the road taken by non-financial information reporting in Romania up to 2013 , before the predecessor of NFRD was issued. Moreover, the debate will reflect the local context 
using the framework of neo-institutional normative theory. A qualitative methodology based on a literature review of the academic debates, as well as a documentary analysis on how prepared Romanian entities are to provide non-financial information, present the transposition process that highlights the harmonization of the Romanian regulation to the EU Directive.

Therefore, this paper contributes to the development of corporate reporting literature, revealing the transposition outcome in the context of the economic-, government- and society-related factors in Romania, taking into consideration the historical, cultural, economic and political local contexts.

\section{- EU Commission ESG debates and NFI reporting evolution}

In Europe, the roadmap for the NFRD was a democratic step-by-step process conducted by the EU Commission, based on a dialogue with the stakeholders, in line with better regulation principles, the transparency of the reporting directive, based on evidence, and backed up through the views of citizens and stakeholders. Going back in time, and following the EU Commission initiatives and documents related to ESG, we can trace the NFRD's evolution using Table 1.

Table 1. EU Commission ESG debates and issues

\begin{tabular}{|l|l|}
\hline \multicolumn{1}{|c|}{ Year } & \\
\hline 1993 & $\begin{array}{l}\text { White paper "Growth competitiveness and employment - the challenges and } \\
\text { ways forward into the 21st century" }\end{array}$ \\
\hline 1995 & Manifesto of European enterprises against social exclusion \\
\hline 1996 & $\begin{array}{l}\text { CSR Europe comes to life in Brussels: as implementation of J. Delors' Manifesto } \\
\text { (1995) and preferential interlocutor of the European Commission }\end{array}$ \\
\hline March 2000 & $\begin{array}{l}\text { Lisbon Summit - Call for corporate social responsibility as instrument to make } \\
\text { "Europe a pole of excellence" }\end{array}$ \\
\hline December 2000 & Nice Summit - Approval of the Social Agenda \\
\hline June 2001 & Goteborg Summit - Strategy for Sustainable Development \\
\hline July 2001 & Green book of the Commission, with the first definition of CSR \\
\hline November 2001 & Brussels - Conference of the Belgian EU Chairmanship on CSR \\
\hline July 2002 & $\begin{array}{l}\text { Commission Communication "Corporate Social Responsibility: A Business } \\
\text { Contribution to Sustainable Development" }\end{array}$ \\
\hline February 2003 & $\begin{array}{l}\text { Multi-stakeholders Forum to define the characteristics and obstacles to the } \\
\text { dissemination of the RSI }\end{array}$ \\
\hline March 2005 & Road map on sustainable enterprise \\
\hline March 2006 & Promotion of an "European Alliance for the RSI" \\
\hline April 2011 & $\begin{array}{l}\text { Commission Communication "Single Market Act I - Twelve Levers to Boost Growth } \\
\text { and Strengthen Confidence" }\end{array}$ \\
\hline October 2011 & $\begin{array}{l}\text { Commission Communication "A renewed EU strategy 2001-2014 for Corporate } \\
\text { Social Responsibility" - a new definition of CSR }\end{array}$ \\
\hline February 2013 & $\begin{array}{l}\text { Parliament Resolutions on “Corporate Social Responsibility: accountable, transparent } \\
\text { and responsible business behaviour and sustainable growth" and on "CSR: } \\
\text { promoting society's interests and a route to sustainable and inclusive recovery" }\end{array}$ \\
\hline Directive 2013/34/EU & Non-financial and diversity information required \\
\hline Directive 2014/95/EU & Mandatory non-financial statement for large undertakings and groups \\
\hline
\end{tabular}

Source: Carini et al., 2018. 
From another angle, this time concerning corporate reporting, there are also EU Commission initiatives that enhanced the role of ESG reporting (Table 2).

Table 2. EU Commission ESG related reporting issues

\begin{tabular}{|c|c|c|}
\hline Year & Items & ESG reporting \\
\hline 2000 & $\begin{array}{l}\text { "EU Financial Reporting } \\
\text { Strategy: The Way } \\
\text { Forward" }\end{array}$ & $\begin{array}{l}\text { "Where appropriate, an analysis of environmental and social } \\
\text { aspects necessary for an understanding of the company's } \\
\text { development, performance or position" should be disclosed as part } \\
\text { of the annual report. }\end{array}$ \\
\hline 2003 & $\begin{array}{l}\text { Directive 2003/51/EC } \\
\text { (Accounts Modernization } \\
\text { Directive) }\end{array}$ & $\begin{array}{l}\text { To the extent necessary for an understanding of the company's } \\
\text { development, performance of position, "information should not be } \\
\text { restricted to the financial aspects" and "where appropriate, this } \\
\text { should lead to an analysis of environmental and social aspects } \\
\text { necessary for an understanding of the company's development, } \\
\text { performance or position". }\end{array}$ \\
\hline 2006 & $\begin{array}{l}\text { Directive } 2006 / 46 / E C \\
\text { on the annual accounts } \\
\text { and consolidated accounts } \\
\text { of certain institutions }\end{array}$ & $\begin{array}{l}\text { All publicly listed companies in Europe had to include a corporate } \\
\text { governance statement in their annual report. }\end{array}$ \\
\hline 2013 & $\begin{array}{l}\text { Directive } 2013 / 34 / E U \\
\text { as regards disclosure of } \\
\text { non-financial and diversity } \\
\text { information by certain large } \\
\text { undertakings and groups }\end{array}$ & $\begin{array}{l}\text { Two major problems related with the NFR across the Union: } \\
\text { (1) the inadequate transparency of the non-financial information } \\
\text { in the business environment, and (2) the insufficient diversity } \\
\text { of the management councils of the companies, which is primarily } \\
\text { considered a matter related to the corporate governance processes }\end{array}$ \\
\hline 2014 & Directive 2014/95/EU & Mandatory non-financial information for large undertakings and groups \\
\hline
\end{tabular}

Source: Own compilation based on EU documents.

The NFRD's objective is to increase the relevance, consistency and comparability of the information disclosed by certain large undertakings and groups across Europe (EU, 2014) and requires large companies to disclose certain information on the way they operate and manage social and environmental challenges. The NFRD lays down the rules on disclosure of non-financial and diversity information by large companies. The entities subject to the Directive are large public-interest entities (PIEs) or groups of entities with more than 500 employees. The EU defines PIEs as undertakings in one of the following situations: listed on a regulated market in any Member State; credit institutions; insurance undertakings; designated by the Member States as PIEs because of the nature of their business, size or number of employees (EU, 2013).

Large companies have to include a brief description of the entity's business model and its policies concerning environmental, social and employee matters, respect for human rights, procedures to counteract corruption and bribery and their outcomes, risks and risk management related to those matters and non-financial key performance indicators (KPI). Companies can apply various frameworks (their own, national, European or international) in providing this information. The disclosure of NFI may be made in a separate NFI statement/report or be included in the management report or annual report under the form of a non-financial statement, so that the statutory auditor will check the existence of the non-financial statement. If companies do not report one of the minimum required information, they must explain why they do not report this information. Moreover, the EU has issued a guideline in 2017, respectively EU Guidelines 2017/C215/01 (EUG), trying to help companies in reporting NFI. The NFRD, together with the EUG, is mandatory for European PIEs to produce and publish NFI to improve the accountability of these European entities to stakeholders. 


\section{Non-financial reporting, between voluntary and mandatory requirements in Europe}

The non-financial reporting topic is debated in the literature from different perspectives. The main areas concern incentives, benefits and weaknesses: company reporting practices; and comparative studies regarding reporting practices in different countries.

Stakeholders play a significant role in the institutionalization of NFI reporting (Gușe et al., 2016) and their pressure resulted in many companies starting to disclose information concerning social, environmental or sustainability issues. Moreover, in some EU countries, like France, Denmark and the UK, NFR is not new, with mandatory NFI requirements existing for certain types of entities.

Currently, there are many standards, guidelines, and frameworks created by global reporting organizations that companies use as a reference for NFI reporting. From the stakeholders' point of view, this diversity in the $\mathrm{NFI}$ reporting practised by companies was a source of confusion, due to the impracticability of meaningfully comparing companies on ESG topics (Bonsón and Bednárová, 2015), over-reporting of inadequate information and insufficient transparency of NFI, and the EU NFRD is seen to be a solution to this problem of low comparability.

Many researchers show interest in the analyses of companies' NFI reporting, being focused on a single state, or conducting comparative studies between states. These studies show the different level of disclosure between regions and industries, in countries with or without a tradition in reporting NFI (Peršić et al., 2017; Dyduch and Krasodomska, 2017; Matuszak and Rózańska, 2017; Aureli et al., 2019; Carini et al., 2018; Manes-Rossi et al., 2018; Sierra-Garcia et al., 2018).

These elements and others related to the national context were explored by researchers, with a specific focus on the context of particular member states, such as Italy (Venturelli et al., 2017; Caputo et al., 2019), France (Malecki, 2018), Germany (Hoffmann et al., 2018), Spain (Sierra-Garcia et al., 2018), Poland (Matuszak and Rózańska, 2017; Maj, 2018) and Romania (Fărcaș, 2020), or comparatively between two or three states, like Poland and Romania (Dumitru et al., 2017) and the UK, France and Italy (Aureli et al., 2019).

In the Eastern European context of emerging markets, in particular, the challenges of transitioning to a market economy faced by these countries after 1990 and disclosing non-mandatory information were marked by over fifty years of socialist principles and therefore the transition in this region appears to be more difficult, in comparison with similar processes in other emerging economies. (MacLullich and Gurau, 2004)

\section{O Methodology}

The institutional theory provides a proper perspective to investigate the evolution of NFI reporting in a national context. In the case of Romania, the institutional theory focuses on the analysis of external factors and their impact. This article explores the impact of the institutional pressure of the EU on the choice made by Member States (Börzel, 2005) for transposing corporate reporting regulations concerning financial and nonfinancial reporting. The EU Directives represent a form of coercive mechanism that should lead to isomorphism. However, compliance with EU regulations may vary because of the role played by different domestic institutions that also exercise pressure (Börzel and Risse, 2003). Previous accounting research demonstrates that national financial reporting regulations are heavily influenced by local factors (e.g., legal system, financing system), and that national differences continue to exist even after the mandatory use of a regulation, e.g., IFRS (International Financial Reporting Standards) for listed companies (Nobes, 2006). Similarly, the countries' institutional factors remain relevant under IFRS and determine international differences in accounting policy choice.

The research methodology focuses on the formal and informal implementation of non-financial reporting. First, we present an overview of the EU Member States practices and regulations concerning non-financial reporting. Secondly, we analyse the process to adopt NFI reporting in Romania, taking into consideration the institutional factors that might influence this process. In the second stage of our research we undertake a critical approach to document analysis, by investigating Romanian regulations related to NFI reporting in the form of both mandatory and optional requirements and practices. The outcome is analysed in light of the economic, 
government and society related factors in Romania (Jamali and Neville, 2011), which define the historical, cultural, economic and political local contexts.

\section{Findings for the pre-NFRD period of NFI reporting in Romania (1990-2013)}

\section{a) Romanian corporate reporting emerging}

The transition process from a centrally planned economy to a market-based economy included a set of complex reforms in the area of property, labour market, capital markets development, currency convertibility, price liberalisation, macro-economic stabilisation and welfare. (MacLullich and Gurau, 2004)

From a regulatory perspective, one might mention the National Environmental Protection Agency set up in 1990, followed in 1995 by the first environmental protection regulations (Law No. 137/1995). Also, in 2000, the anti-bribery and corruption Law No. 78/2000 was issued, and two years later, the National Anticorruption Directorate was set up. In addition to the Companies Law No. 31/1990, a Sponsorship Law (No. 32/1994) was issued in direct relation to social responsibility. In this period, the social responsibility of Romanian companies was understood mainly as corporate philanthropy because of a weak civil society.

The legislative framework was also strengthened by the issuance of Law No. 11/1991 concerning unfair competition, the Competition Law No. 21/1996, the Fiscal Code Law No. 571/2003, the Labour Code Law No. 53/2003, Law No. 319/2006 on workplace security and health, and Law No. 30/1994 concerning the defence of human rights. Also, it's worth mentioning the Romanian commitment to sustainable development, being the first European country to ratify the Kyoto Protocol in 1992, a member of the International Labour Organization (ILO), and ratifying the United Nations Framework Convention on Climate Change Law No. 24/1994.

At the beginning of 1990, the accounting system was reshaped to correspond to a market economy. The changes to the accounting system were determined by structural changes in how the economy operated (Duția, 1995; MacLullich and Gurau, 2004). One of the most significant changes that affected the accounting system was due to the new companies, with private ownership, for which a new accounting system was needed.

Concerning corporate reporting, generally, according to the Romanian regulations (Accounting Law No. 82/1991 and the regulation regarding its application introduced by GD No. 704/1993), the corporate annual reports published by companies include the following elements: the financial statements, the decisions of the general assembly of shareholders, the administrator's report and the report of the censor. No reference is found in the Romanian corporate reporting regulations concerning NFI during 1990-1998, also known as the first period of the Romanian accounting reforms, characterised by moving to market economy principles.

\section{b) First mentions concerning NFI in Romanian corporate reporting regulations}

Starting with 1999, Romanian accounting regulations were harmonised with the EU Directives and strategies, such as the 2000 "EU Financial Reporting Strategy: The Way Forward" and the Accounts Modernization Directive 2003/51/EC (OMPF No. 403/1999, followed by OMPF No. 94/2001 and OMPF No. 1121/2006 for listed companies and non-listed companies, OMPF No. 306/2002, and OMPF No. 1752/2005), in the collective legislative harmonization effort done in Romania's pre-accession to EU period. After becoming an EU Member, Romanian corporate financial reporting entered in the alignment phase with the EU reporting regulations (OMPF No. 3055/2009) and additional regulations for listed companies (OMPF No. 1286/2012).

Romania followed the path traced by the 2000 "EU Financial Reporting Strategy: The Way Forward" and the EU Accounts Modernisation Directive 2003/51/EC, which required European companies to disclose as part of the annual report where appropriate, analyses of environmental and social aspects necessary for an understanding of the company's development, performance or position' as specific non-financial key performance indicators, and introduced some recommendations concerning non-financial reporting.

In the corporate reporting regulations issued by the Ministry of Public Finance, there are mentions related to $\mathrm{NFI}$ disclosure by the management reporting in a voluntary minimalistic manner, using the same wording as 
in the EU regulations, as it can be seen for example below in OMPF No. 1752/2005, Section 9, Art. 259, OMPF No. 3055/2009, Section 10, Art. 305, and OMPF No. 1286/2012. The Administrators'/Directors'/Management's report includes at least a fair presentation of the development and performance of the entity's activities and its position, together with a description of the main risks and uncertainties it faces. The presentation is a balanced and comprehensive analysis of the development and performance of the entity's activities and financial position in correlation with the activities' size and complexity: "To the extent necessary to understand the entity's development, performance or financial position, the analysis shall include financial indicators and, where appropriate, key non-financial performance indicators, relevant to specific activities, including information on issues concerning the environment and employees."

\section{c) Mandatory NFI reporting for Romanian listed companies}

Starting with 2006, the Romanian National Securities Commission's (CNVM) Regulation No. 1/2006 (CNVM, 2006, Art. 226) requires listed companies to present "a fair and complete review of the development and performance of the business of the issuer together with a description of the main risks and uncertainties specific to the performed activity", and "the reporting shall include any significant information so that investors may make an informed assessment of the activity of the company, of its profit and loss, and in such a way so that it shows any special factors that have influenced these activities". Moreover, an external auditor's report is required. Furthermore, an annual report of the board of directors (CNVM, 2006, Art. 112), for which the regulation provides a structured model developed in sections, each with detailed elements, is required to be disclosed starting with 2006. According to this regulation, NFI became mandatory for listed entities, disclosed via the management's report. The model contains a detailed description of the company's activities, main products and services, its position on the market, clients and suppliers, competitors and other elements. A specific section is dedicated to social, environmental and governance issues.

"1.1.5. Evaluation of the aspects related to the company's employees/staff: a) Specifying the number and level of training of the company's employees, as well as the unionization of the labour force; $b$ ) The description of the relations between the manager and the employees as well as of any conflicting elements that characterize these relations.

1.1.6. Assessment of the aspects related to the impact of the issuer's core business on the environment. A brief description of the impact of the issuer's core business activities on the environment, as well as any existing or expected litigation regarding the violation of environmental protection legislation.

1.1.7. Evaluation of the research and development activity. Specifying the expenses in the financial year, as well as those that are anticipated in the next financial year for the research and development activity.

1.1.8. Evaluation of the company's activity regarding risk management. Description of the company's exposure to price, credit, liquidity and cash flow risk. Description of the company's policies and objectives on risk management."

In line with CNVM's position about the disclosure of non-financial information, the Bucharest Stock Exchange (BSE) played an active role by issuing the Corporate Governance Code in 2009, mandatory for listed companies, requiring the disclosure of the involvement in CSR and the presentation of non-financial information concerning social, environmental and governance matters.

\section{d) Practices concerning NFI disclosure in Romanian companies}

Nevertheless, even if the regulatory framework for NFI exists, technically being mandatory for listed companies, such reporting was seldom presented in the first place, and not at all as detailed as required by the regulation. Concerning Romanian listed companies for the year 2013, Mocanu and Roman (2016) conclude that most companies simply state that they have the operating, sanitary, veterinary and environmental authorizations which are stipulated by law for the activities they carry out. The companies prefer to mention, in relation to the legal provisions, that their operations do not have a significant environmental impact, and no litigation regarding a violation of environmental regulations exists or is foreseen in the future (Mocanu and Roman, 2016). 
CSR reporting in Romania is studied using the case of listed companies, through the role of the stakeholders in its institutionalization (Gușe et al., 2016), or specific issues like environmental information disclosure (Istrate et al., 2017) and financial performance. Using a sample of 20 non-financial listed companies on the Bucharest Stock Exchange included in the BET Plus Index, Dumitru et al. (2017) analysed the CSR disclosures presented by the companies in Management Reports for the year 2014. To assess the quality of the CSR disclosure, a score related to the type of disclosures was used for each analysed element: 0 - no presentation; 1 - narrative presentation; 2 - presentation using KPIs or other numerical/quantitative data; $3(1+2)$ - narrative and numerical presentation at the same time. The higher the score, the better the CSR disclosure quality, with a possible maximum of 60 . By using an indication of both the completeness (i.e., the number of disclosed CSR items) and the comprehensiveness of NFR, the study gives a clearer indication of what and how companies disclose in terms of governance, social, environmental and ethical matters, as required by Directive 2013/34/EU.

Concerning CSR reports, there is a definite tendency in the case of Romanian companies to report CSR practices. In particular, companies with foreign capital or which are part of multinational groups with affiliates in Romania are publishing corporate governance reports, CSR Reports, Ethics Codes (Dumitrescu and Simionescu, 2014, 2015).

A possible conclusion revealed by the table below, and data and studies mentioned before concerning the NFI reporting in the pre-NFRD period in Romania might be that companies which are part of international groups make more NFR disclosures than the other companies. Concerning the sector and ownership, environmentally sensitive companies and state-owned companies present NFI reports. These companies are using NFR international frameworks, and the majority have Big 4 auditors (Dumitru et al., 2017).

Analysing the evolution of NFI reporting studies in Romania, there is a positive trend; companies seem to engage in environmental initiatives, moving in time from disclosing low quality, inconsistent information, in the first period, to more consistent information (Dumitru et al., 2017; Tiron-Tudor et al., 2019).

The CSR Report (2018) also confirms this status, as shown in the following table:

Table 3. CSR Reports

\begin{tabular}{|c|c|c|c|c|c|c|c|c|c|c|c|c|c|c|c|c|}
\hline \multirow{2}{*}{ Company name } & \multirow{2}{*}{$\begin{array}{c}\text { Reports } \\
\text { No. }\end{array}$} & \multicolumn{15}{|c|}{ Period } \\
\hline & & 2003 & 2004 & 2005 & 2006 & 2007 & 2008 & 2009 & 2010 & 2011 & 2012 & 2013 & 2014 & 2015 & 2016 & 2017 \\
\hline Orange Romania & 5 & $x$ & $x$ & $x$ & $x$ & & & $x$ & & & & & & & & \\
\hline Holcim Romania & 6 & & $x$ & $x$ & $x$ & $x$ & $x$ & \multicolumn{2}{|c|}{$x$} & & & & & & & \\
\hline Siveco Romania & 6 & & & & & & $x$ & $x$ & $x$ & $x$ & $x$ & $x$ & & & & \\
\hline OTP Bank & 7 & & & & & & $x$ & $x$ & $x$ & $x$ & $x$ & $x$ & $x$ & & & \\
\hline $\begin{array}{l}\text { Provident Financial } \\
\text { Romania }\end{array}$ & 2 & & & & & & $x$ & & $x$ & & & & & & & \\
\hline $\mathrm{BCR}$ & 2 & & & & & & \multicolumn{2}{|l|}{$x$} & $x$ & & & & & & & \\
\hline Raiffeisen Bank & 9 & & & & & & & $x$ & $x$ & $x$ & $x$ & $x$ & $x$ & $x$ & $x$ & $x$ \\
\hline Heineken Romania & 6 & & & & & & & & $x$ & $x$ & $x$ & $x$ & $x$ & $x$ & & \\
\hline Telekom Romania & 6 & & & & & & & & $x$ & $x$ & $x$ & & $x$ & $x$ & $x$ & \\
\hline Ursus Breweries & 4 & & & & & & & & \multicolumn{3}{|c|}{$x$} & $x$ & $x$ & \multicolumn{2}{|c|}{$x$} & \\
\hline Romradiatoare SA & 4 & & & & & & & & & $x$ & $x$ & $x$ & $x$ & & & \\
\hline GSK Romania & 5 & & & & & & & & & $x$ & $x$ & $x$ & \multicolumn{2}{|c|}{$x$} & \multicolumn{2}{|c|}{$x$} \\
\hline OMV Petrom & 5 & & & & & & & & & $x$ & $x$ & $x$ & & & $x$ & $x$ \\
\hline HeidelbergCement & 2 & & & & & & & & & $x$ & $x$ & k & & & & \\
\hline $\begin{array}{l}\text { Coca-Cola HBC } \\
\text { Romania }\end{array}$ & 3 & & & & & & & & & $x$ & \multicolumn{3}{|c|}{$x$} & $\mathrm{x}$ & & \\
\hline Lafarge Romania & 1 & & & & & & & & & & $x$ & & & & & \\
\hline
\end{tabular}




\begin{tabular}{|c|c|c|c|c|c|c|c|c|c|c|c|c|c|c|c|c|}
\hline \multirow{2}{*}{ Company name } & \multirow{2}{*}{$\begin{array}{c}\text { Reports } \\
\text { No. }\end{array}$} & \multicolumn{15}{|c|}{ Period } \\
\hline & & 2003 & 2004 & 2005 & 2006 & 2007 & 2008 & 2009 & 2010 & 2011 & 2012 & 2013 & 2014 & 2015 & 2016 & 2017 \\
\hline KPMG Romania & 2 & & & & & & & & & & $\mathrm{x}$ & $\mathrm{x}$ & & & & \\
\hline Auchan Romania & 2 & & & & & & & & & & $\mathrm{x}$ & $\mathrm{x}$ & & & & \\
\hline ArcelorMittal & 3 & & & & & & & & & & & $x$ & $x$ & $x$ & & \\
\hline $\begin{array}{l}\text { KMG International } \\
\text { (Rompetrol) }\end{array}$ & 1 & & & & & & & & & & & & $x$ & & & \\
\hline Maguay Romania & 1 & & & & & & & & & & & & $\mathrm{x}$ & & & \\
\hline Insoft Romania & 1 & & & & & & & & & & & & & $\mathrm{x}$ & & \\
\hline Farmaciile Dona & 1 & & & & & & & & & & & & & & $x$ & \\
\hline Electrica & 1 & & & & & & & & & & & & & & $\mathrm{x}$ & \\
\hline CEZ Group Romania & 1 & & & & & & & & & & & & & & $\mathrm{x}$ & \\
\hline $\begin{array}{l}\text { Distribuție Energie } \\
\text { Oltenia }\end{array}$ & 1 & & & & & & & & & & & & & & $\mathrm{x}$ & \\
\hline Kaufland Romania & 1 & & & & & & & & & & & & & & $x$ & \\
\hline Lidl Romania & 1 & & & & & & & & & & & & & & $x$ & \\
\hline Transelectrica & 1 & & & & & & & & & & & & & & & $\mathrm{x}$ \\
\hline Total & & 1 & 2 & 2 & 2 & 1 & 5 & 6 & 9 & 11 & 14 & 14 & 11 & 8 & 11 & 4 \\
\hline
\end{tabular}

Source: http://www.csrreport.ro/director-raportori

\section{Discussions and conclusions concerning NFRD transposition in the specific local context}

This paper investigates non-financial disclosures in Romania, prior to the European Directive's adoption. Romania shifted from a centralized economy to a market economy, and undertook substantial socio-political transformations, with positive results. The country's economic growth has been high in comparison with the EU Member States since 2010. The reforms were spurred by the accession to the European Union, boosting productivity and integrating Romania into the EU economic space. However, growth is limited by a weak commitment to policy implementation, which creates a poor business environment. For these reasons, Romania is still a developing country with an emerging economy, and as a consequence, the companies' responsibilities for the social and environmental consequences of their actions are not high.

The NFI reporting represents a relatively new issue for the Romanian environment, if we take into consideration the fact that only after 1990, when Romania moved from a communist, centralised economy to a market economy with private companies, allowing for corporate social responsibility activities and reporting to arise voluntarily. The CSR concept become known only after 1990 in Romania, being introduced by foreign multinational companies and non-profit organizations. Also, during the same period, the state started to build up the legislative framework and institutions.

Romania has no tradition in terms of policies and CSR disclosure practices, and societal pressure toward CSR, because of the historical and socio-economic development. Nevertheless, in the last 30 years, cultural and educational changes emerged, triggered by the transition from a centrally planned economy to the free-market system, and there are actions and initiatives in the CSR area, such as the mentioned CSR Report and others.

The non-financial reporting of social, environmental and governance issues in Romania is a clear result of the institutional pressure. The lack of voluntary disclosure may be considered a legacy of the communist regime, when "voluntary work" meant unpaid and mandatory activities, imposed by the communist public administration on its citizens, and the traditional character of the Romanian society in which social connection was "exclusively confined to family ties; and the lack of social trust in other reference groups outside of the family circle". (Voicu and Voicu, 2003) Moreover, being a rule-based legislative system, the companies' social, the disclosure of social, environmental and governance matters will increase after the issuance of the national regulations, as a result of a constraint enforced by the state. Still, in these conditions, further research will show 
if NFR will remain a "formal" imposed way of discharging the company management's legal responsibilities, or it will become a real tool that might contribute to increased transparency and accountability and to building a trust-based relationship with stakeholders.

\section{Bibliography}

1. Aureli, S., Magnaghi, E., Salvatori, F. (2019), The Role of Existing Regulation and Discretion in Harmonising Non-Financial Disclosure, Accounting in Europe, Vol. 16, No. 3, pp. 290-312.

2. Bonsón, E., Bednárová, M. (2015), CSR Reporting Practices of Eurozone Companies, Spanish Accounting Review, Vol. 18, No. 2, pp. 182-193.

3. Börzel, T.A. (2005), Europeanization: How the European Union Interacts with its Member States, in S. Bulmer, C. Lequesne (Eds.), The Member States of the European Union, Oxford University Press, Oxford, pp. 43-69.

4. Börzel, T.A., Risse, T. (2003), Conceptualizing the Domestic Impact of Europe, in C.M. Radaelli, K. Featherstone (Eds.), The Politics of Europeanization, Oxford University Press, Oxford, pp. 57-81.

5. Caputo, F., Leopizzi, R., Pizzi, S., Milone, V. (2019), The Non-Financial Reporting Harmonization in Italian Context, Sustainability 2020, Vol. 12, 92.

6. Carini, C., Rocca, L., Veneziani, M., Teodori, C. (2018), Ex-Ante Impact Assessment of Sustainability Information - The Directive 2014/95, Sustainability, Vol. 10, 560.

7. Dumay, J., La Torre, M., Farneti, F. (2019), Developing Trust Through Stewardship: Implications for Intellectual Capital, Integrated Reporting, and the EU Directive 2014/95/EU, Journal of Intellectual Capital, Vol. 20, No. 1, pp. 11-39.

8. Dumitrescu, D., Simionescu, L. (2014), Should Developing Countries Adopt Corporate Social Responsibility? Empirical Evidence from Romania, Journal of Economic Computation and Economic Cybernetics Studies and Research, Vol. 48, No. 2, pp. 19-36.

9. Dumitrescu, D., Simionescu, L. (2015), Empirical Research Regarding the Influence of Corporate Social Responsibility (CSR) Activities on Companies' Employees and Financial Performance, Journal of Economic Computation and Economic Cybernetics Studies and Research, Vol. 49, No. 3, pp. 52-66.

10. Dumitru, M., Dyduch, J., Gușe, R.-G., Krasodomska, J. (2017), Corporate Reporting Practices in Poland and Romania - An Ex-Ante Study to the New Non-Financial Reporting European Directive, Accounting in Europe, Vol. 14, No. 3, pp. 279-304.

11. Duția, T. (1995), The Restructuring of the System of Accounting in Romania During the Period of Transition to the Market Economy, European Accounting Review, Vol. 4, No. 4, pp. 739-748.

12. Dyduch, J., Krasodomska, J. (2017), Determinants of Corporate Social Responsibility Disclosure: An Empirical Study of Polish Listed Companies, Sustainability, Vol. 9, 1934.

13. Fărcaş, T.V. (2020), Study about the Implementation of the Directive 95/2014 in Romania-Legislative Perspective and the Actual Application, Audit financiar, nr. 2, pp. 339-351.

14. Guşe, G.R., Almăşan, A., Circa, C., Dumitru, M. (2016), The Role of the Stakeholders in the Institutionalization of the CSR Reporting in Romania, Accounting and Management Information Systems, Vol. 15, No. 2, pp. 304-340.

15. Hoffmann, E., Dietsche, C., Hobelsberger, C. (2018), Between Mandatory and Voluntary: Non-Financial Reporting by German Companies, Sustainable Management Forum, Vol. 26, No. 1, pp. 47-63.

16. Istrate, C., Robu, I.-B., Păvăloaia, L., Herghiligiu, I.V. (2017), Analysis of Companies Sustainability under the Influence of Environmental Information Disclosure, Environmental Engineering and Management Journal, No. 16, pp. 957-967.

17. Jamali, D., Neville, B. (2011), Convergence Versus Divergence of CSR in Developing Countries: An Embedded Multi-Layered Institutional Lens, Journal of Business Ethics, Vol. 102, pp. 599-621.

18. MacLullich, K.K., Gurau, C. (2004), The Relationship between Economic Performance and Accounting System Reform in the CEE Region: The Cases of Poland and Romania, CEFT, Discussion Paper 2004/06.

19. Maj, J. (2018), Nature of Non-Financial Information Disclosed by Polish Organisations, in Proceedings of the 31st International Business Information Management Association Conference, Milan, pp. 640-648. 
20. Makarenko, I., Sirkovska, N. (2017), Transition to Sustainability Reporting: Evidence from EU and Ukraine, Business Ethics and Leadership, Vol. 1, pp. 16-24.

21. Malecki, C. (2018), French Implementation of the EU CSR Directive: Sustainable Corporate Governance Has Begun, Law and Financial Markets Review, Vol. 12, No. 2, pp. 86-92.

22. Manes-Rossi, F., Tiron-Tudor, A., Nicolò, G., Zanellato, G. (2018), Ensuring More Sustainable Reporting in Europe Using Non-Financial Disclosure - De Facto and De Jure Evidence, Sustainability, Vol. 10, No. 4, 1162.

23. Matuszak, Ł., Rózańska, E. (2017), CSR Disclosure in Polish-Listed Companies in the Light of Directive 2014/95/EU Requirements: Empirical Evidence, Sustainability, Vol. 9, 2304.

24. Mocanu, M., Roman, A.-G. (2016), Financial and Non-Financial Reporting in Romanian Entities Operating in Agriculture, Forestry, and Fishery, Audit financiar, Vol. XIV, No. 6, pp. 659-669.

25. Nobes, Ch. (2006), The Survival of International Differences under IFRS: Towards a Research Agenda, Accounting and Business Research, Vol. 36, No. 3, pp. 233-245.

26. Peršić, M., Janković, S., Krivačić, D. (2017), Sustainability Accounting: Upgrading Corporate Social Responsibility, CSR, Sustainability, Ethics \& Governance, pp. 285-303.

27. Sierra-Garcia, L., Garcia-Benau, M., Bollas-Araya, H. (2018), Empirical Analysis of Non-Financial Reporting by Spanish Companies, Administrative Sciences, Vol. 8, No. 3.

28. Tiron-Tudor, A., Nistor, C.S., Ştefănescu, C.A., Zanellato, G. ( 2019), Encompassing Non-Financial Reporting in a Coercive Framework for Enhancing Social Responsibility: Romanian Listed Companies Case, Amfiteatrul Economic, vol. 21, nr. 52, pp. 590-606.

29. Tschopp, D., Huefner, R.J. (2014), Comparing the Evolution of CSR Reporting to that of Financial Reporting, Journal of Business Ethics, Vol. 127, No. 3, pp. 565-577.

30. Venturelli, A., Caputo, F., Cosma, S., Leopizzi, R., Pizzi, S. (2017), Directive 2014/95/EU: Are Italian Companies Already Compliant?, Sustainability, Vol. 9, 1385.

31. Voicu, M., Voicu, B. (2003), Volunteering in România: A Rara Avis, in L. Halman, P. Dekker (Eds.), The Values of Volunteering. Cross-Cultural Perspective, Kluwer Academic/Plenum Publishers, New York, pp. 143-160.

32. CNVM (2006), Regulation No. 1/2006 on issuers of and operations with securities (Regulamentul nr. 1/2006 privind emitenții şi operațiunile cu valori mobiliare).

33. European Union (2000), EU Financial Reporting Strategy: The Way Forward.

34. European Union (2003), Directive 2003/51/EC of the European Parliament and of the Council of 18 June 2003 amending Directives 78/660/EEC, 83/349/EEC, 86/635/EEC and 91/674/EEC on the annual and consolidated accounts of certain types of companies, banks and other financial institutions and insurance undertakings, Official Journal No. L 178/17.07.2003.

35. European Union (2013), Directive 2013/34/EU of the European Parliament and of the Council of 26 June 2013 on the annual financial statements, consolidated financial statements and related reports of certain types of undertakings, amending Directive 2006/43/EC of the European Parliament and of the Council and repealing Council Directives 78/660/EEC and 83/349/EEC, Official Journal No. L 182/29.06.2013.

36. European Union (2014), Directive 2014/95/EU of the European Parliament and of the Council of 22 October 2014 amending Directive 2013/34/EU as regards disclosure of non-financial and diversity information by certain large undertakings and groups, Official Journal No. L 330/15.11.2014.

37. Order of the Minister of Public Finance No. 1286/2012 for the approval of the Accounting regulations according to the International Financial Reporting Standards, applicable to the companies whose securities are traded on a regulated market, Official Journal No. 687/04.10.2012, with subsequent amendments and supplements.

38. Order of the Minister of Public Finance No. 1802/2014 for the approval of the Accounting regulations regarding the individual annual financial statements and consolidated annual financial statements, Official Journal No. 963/30.12.2014, with subsequent amendments and supplements.

39. http://www.csrreport.ro/director-raportori

40. www.slideshare.net/TheCSRReport/cele-680-de-companii-din-romania-obligate-sa-raporteze-nonfinanciar 